\title{
Three-Phase Approach for Developing Suitable Business Models for Exchanging Federated ERP Components as Web Services
}

\author{
Evan Asfoura ${ }^{1}$, Mohammad Samir Abdel-Haq ${ }^{2}$, Houcine Chatti ${ }^{3}$ \\ Department of Management information system \\ Dar Al Uloom University \\ Riyadh /Saudi Arabia
}

\begin{abstract}
The importance of business models has increased significantly in the last decade, especially in the Internet. The cause of this increase is the effect of Internet and the associated applications and their business processes regarding to the business model. These effects include, for example, the emerging technical and economic aspects of a business model on the Internet, the support and transformation of traditional business models, and the arise of new business ideas based on that technology. One of these new ideas is: how distributed Enterprise Resource Planning (ERP) systems or federated ERP (FERP) systems as web services (WSs) can cover the increasing demands of small and medium sized enterprises (SMEs) for business software covered.This paper aims to provide a derived developing approach with three phases that will lead to three suitable concepts that identify suitable business model for FERP System with different scenarios of value exchanging. The results of this work will be conceptual models that describe the character, role and revenue models that identify FERP exchanging business model.
\end{abstract}

Keywords-FERP system; ERP web services; FERP mall; ERP workflow; developing approach

\section{INTRODUCTION}

An enterprise resource planning (ERP) system is a standard software system, which provides functionalities to integrate and automate the business practices associated with the business process of an enterprise. The integration is based on a common data model for all system components and extents to more than one enterprise sectors $[2 ; 27 ; 36 ; 38 ; 49 ; 4]$

The increasing number of the small and medium enterprises' employees extended the need for flexible functionalities in ERP systems. Small and medium sized enterprises (SMEs) are facing different problems when they buy ERP systems, such as [1, 12, 19]

- Not all installed components are needed.

- The usage of licenses, Administration, and maintenance of these products are too expensive.

- Normally, ERP systems are complex and overloaded with stuff, functions and options, therefore it is hard for new user to learn.

- High-end Hardware is required.
Therefore, in the last few years the idea of the Federated ERP-System in the basis of Web-Services has evolved. A federated ERP (FERP) system (see figure 1) is an ERP system, which consists of system components that are distributed within a computer network. The overall functionalities are provided by an ensemble of allied network nodes that all together appear as a single ERP system to the user. Different ERP system components can be developed by different vendors $[1 ; 19 ; 20 ; 23]$. Through the FERP system, enterprises pay only for components deemed necessary. Also, the needed end-hardware is made available by the service provider, which in turn, reduces costs [19].

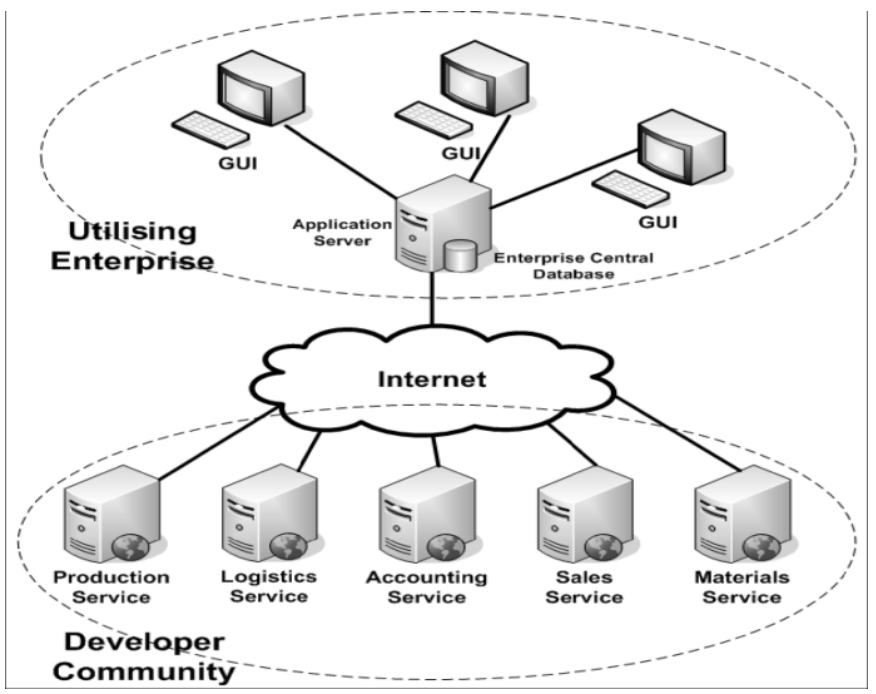

Fig. 1. Architecture of FERP systems [19].

An ERP system component in this case is reusable, closed and marketable software module, which provides services over a well-defined interface. These components can be combined with other components in an unpredictable manner [47] Those components are described, published and used as Web services

A web service is a software system designed to support interoperable machine-to-machine interaction over a network. It has an interface described in a machine-processable format (specifically WSDL). Other web systems interact with the web services in a manner prescribed by its description using SOAPmessages typically conveyed using HTTP with an XML serialization in conjunction with other web-related standards [53] The search for these services by FERP Systems is covered 
by the functionality, which is considered as the logical and stable construction stone in ERP system [19].

FERP system is considered as an advanced Software as a service paradigm, which is provided from various, and independent ERP web services providers. As a service paradigm has been widely from the technical side $[16 ; 18 ; 21 ; 44,24,25]$. Therefore, we will focus in this paper on value exchanging and integrating of Software as service through providing logical developing approach of appropriate business model concepts for exchanging FERP components as web services. The realization of FERP scenario are divided into two processes:

- Production process: focus on the isolation of ERP components, description, publishing those components as web services through the web standards and the integration of these web services in FERP workflows.

- Marketing process: focus on the Exchanging of ERP components as web services need through a suitable business model. Therefore, businesses should be adopted to fulfil the new idea's need.

This paper will focus on the marketing process to find out the suitable business model concept for exchanging of FERP components as ERP web services. Therefore, the aim of this work is to present an derived developing approach with three phases that will lead to three suitable concepts that identify suitable business model for FERP System with different scenarios of value exchanging, The results of this work will be conceptual models that describe the character, role and revenue models that identify FERP exchanging business model.

In the second section of this work, we will present the research methods for formulizing the suitable developing approach, which will lead to the targeted business model concepts as results with qualitative and quantitate evaluation. In the third and fourth section, in fifth section we will discuss the result of this work to explain the added value from this scientific work. The last section will includes the conclusion and the work summary.

\section{Research Methods AND Results}

The paper is exploratory and conceptual in nature and builds on existing literature research. Through literature review and crossing the business model definitions by many researchers and experts in business model field (see table 1). Table 1 has been identifies four characteristics through the meeting points of the definitions of business models that can be considered for the characterization of business model types on the Internet $[8,9,10,11]$. These characteristics and their attributes are: integration in internet economy (IG in IE), targeted business field, products and offered goods and revenue model which includes revenue source and form. The basic model type related to offered goods (see [52]) should be considered in addition to the characteristics that has been shown in Table 1 for the realization of a new business models (see table 2).

There are many business models depending on business field, e.g., business-to-business (B2B), business to customer (B2C), customer-to-customer (C2C), customer to business
(C2B), administration-to-administration (A2A), administration to business (A2B), business to administration (B2A), etc. In this paper we will focus on the most popular models which are (B2B), (B2C) and (C2C) (for more details [5, 30]. Not all products or goods can be traded alike through E-markets. There are many factors (related to the vendor or to the customer) that could affect the trading process [43]. These goods are divided into two categories: Material goods and immaterial goods $[31 ; 39 ; 43,45]$

TABLE I. CRosS OF BUSINESS MODEL DEFINITIONS By MANY RESEARCHERS AND EXPERTS IN BUSINESS MODEL [17]

\begin{tabular}{|c|c|c|c|c|}
\hline Definitions by & $\begin{array}{r}\text { Integrati } \\
\text { on grad } \\
\text { in the } \\
\text { Internet } \\
\text { economy }\end{array}$ & $\begin{array}{r}\text { The } \\
\text { Actors } \\
\text { And } \\
\text { busines } \\
\text { s fields }\end{array}$ & $\begin{array}{r}\text { Produc } \\
\text { ts and } \\
\text { Offere } \\
\text { d } \\
\text { goods }\end{array}$ & $\begin{array}{r}\text { Cash } \\
\text { flow } \\
\text { and } \\
\text { reven } \\
\text { ue }\end{array}$ \\
\hline [46] & & $\mathbf{X}$ & $\mathbf{X}$ & $\mathbf{X}$ \\
\hline [54] & & $\mathbf{X}$ & $\mathbf{X}$ & $\bar{X}$ \\
\hline [55] & & $\mathbf{X}$ & & $\mathbf{X}$ \\
\hline [56] & & $\mathbf{X}$ & $\mathbf{X}$ & $\mathbf{X}$ \\
\hline [39] & $\mathbf{X}$ & $\mathbf{X}$ & $\mathbf{X}$ & $\mathbf{X}$ \\
\hline [3] & & & $\mathbf{x}$ & $\mathbf{x}$ \\
\hline [26] & & & $\mathbf{x}$ & $\mathbf{X}$ \\
\hline [32] & & $\mathbf{x}$ & $\mathbf{x}$ & $\mathbf{X}$ \\
\hline$[40]$ & & & $\mathbf{x}$ & $\mathbf{X}$ \\
\hline [13] & & $\mathbf{x}$ & $\mathbf{x}$ & $\mathbf{X}$ \\
\hline [37] & $\mathbf{x}$ & & & $\mathbf{X}$ \\
\hline [51] & & $\mathbf{x}$ & $\mathbf{x}$ & $\mathbf{X}$ \\
\hline
\end{tabular}

The degree of integration in the internet's economy depends on the ability to implement the transaction phases electronically, distinguished here: full and partial integration [5]: The relevant 4-basic business models types are "content", "connection", "commerce" and "context" [52] The fact is that most of business models belong to one of the 4-Basics types. a business model could be a hybrid of more than one type. 4Basic types [35]

TABLE II. The SELECTED Characteristics AND THEIR ATtRibutes

\begin{tabular}{|c|c|c|c|c|c|c|c|}
\hline Characteristics & \multicolumn{7}{|c|}{ Attributes } \\
\hline ID in IE & \multicolumn{2}{|l|}{ Full } & \multicolumn{5}{|l|}{ Partial } \\
\hline Business field & \multicolumn{2}{|l|}{$\mathrm{B} 2 \mathrm{~B}$} & B2C & \multicolumn{4}{|l|}{$\mathrm{C} 2 \mathrm{C}$} \\
\hline $\begin{array}{l}\text { Basic business } \\
\text { models }\end{array}$ & Content & Context & \multicolumn{2}{|c|}{$\begin{array}{l}\text { Com } \\
\text { mer } \\
\text { ce }\end{array}$} & \multicolumn{3}{|c|}{ Connection } \\
\hline & \multicolumn{2}{|c|}{ Tangabile Goods } & \multicolumn{5}{|c|}{ Intangabile Goods } \\
\hline Offered goods & $\begin{array}{l}\text { Physical } \\
\text { Products }\end{array}$ & $\begin{array}{l}\text { Physical } \\
\text { Services }\end{array}$ & $\begin{array}{l}\text { Digital } \\
\text { Product } \\
\mathrm{s}\end{array}$ & $\begin{array}{l}\text { Digital } \\
\text { Service } \\
\mathrm{s}\end{array}$ & $\begin{array}{l}\text { Info } \\
\text { ion }\end{array}$ & & $\begin{array}{l}\text { Speci } \\
\text { al } \\
\text { goods }\end{array}$ \\
\hline $\begin{array}{l}\text { Revenue } \\
\text { sources }\end{array}$ & \multicolumn{2}{|l|}{ Products } & $\begin{array}{l}\text { cont } \\
\text { acts }\end{array}$ & & \multicolumn{3}{|c|}{ Information } \\
\hline Revenueform & \multicolumn{2}{|c|}{$\begin{array}{l}\text { direct and } \\
\text { transaction } \\
\text { dependent }\end{array}$} & $\begin{array}{l}\text { direct } \\
\text { and } \\
\text { transact } \\
\text { ion } \\
\text { indepen } \\
\text { dent }\end{array}$ & \multicolumn{2}{|c|}{$\begin{array}{l}\text { indirect and } \\
\text { transaction } \\
\text { dependent }\end{array}$} & \multicolumn{2}{|c|}{$\begin{array}{l}\text { indirect } \\
\text { and } \\
\text { transactio } \\
\mathrm{n} \\
\text { independe } \\
\mathrm{nt}\end{array}$} \\
\hline
\end{tabular}


The sources of revenue of business models fall into three categories: Products, contacts and information [42,52] The forms of revenue were classified by Wirtz on one hand according to the players (i.e., buyers and sellers) into direct and indirect revenue and on the other hand according to the pricing conditions into transaction-dependent and transactionindependent [52].

In the next, we will present an approach for developing of appropriate business model for federate ERP systems through logical steps. Through the characteristics of business model which has been shown in the second section we present in the following figure a developing approach which lead us to the appropriate concept for the exchange of FERP components as web services (see figure 2). This developing approach consists of three phases every phase involves one or more of steps with the considering of the existent models, architectures and the special requirements of an FERP system.

The first phase is the characterization phase: In this phase we should answer the following three questions

- Which business model type nowadays is existed and more suitable for FERP as a new Business idea?

- What could be provided in the expected business model?
- To which business fields belongs this business model?

These three questions can be answered and analyzed by using the characteristics "Business Fields", "Basic Business Models" and "Offered Goods" defined in table 2.

The second phase is the adapting phase: This phase aims to identifying the roles of the actors during the transaction phases and the exchange of services with taking into accountminimizing potential problems and risks in the case of FERP systems.

The third phase is the goal phase: This phase characterizes the revenue model depending on the offers and the actors roles with considering the appropriate pricing models

Then this developing approach in figure 2 is derived from the table 2. Table 2 serves information for classifying the existing business models. In contrary, the approach in figure 2 presents basics phases for developing a new business model for a new business idea.

The targeted results of this developing approach are a character-concept, role-concept and revenue-concept of an suitable business model for exchanging FERP systems as Web services. In the flowing subsections.

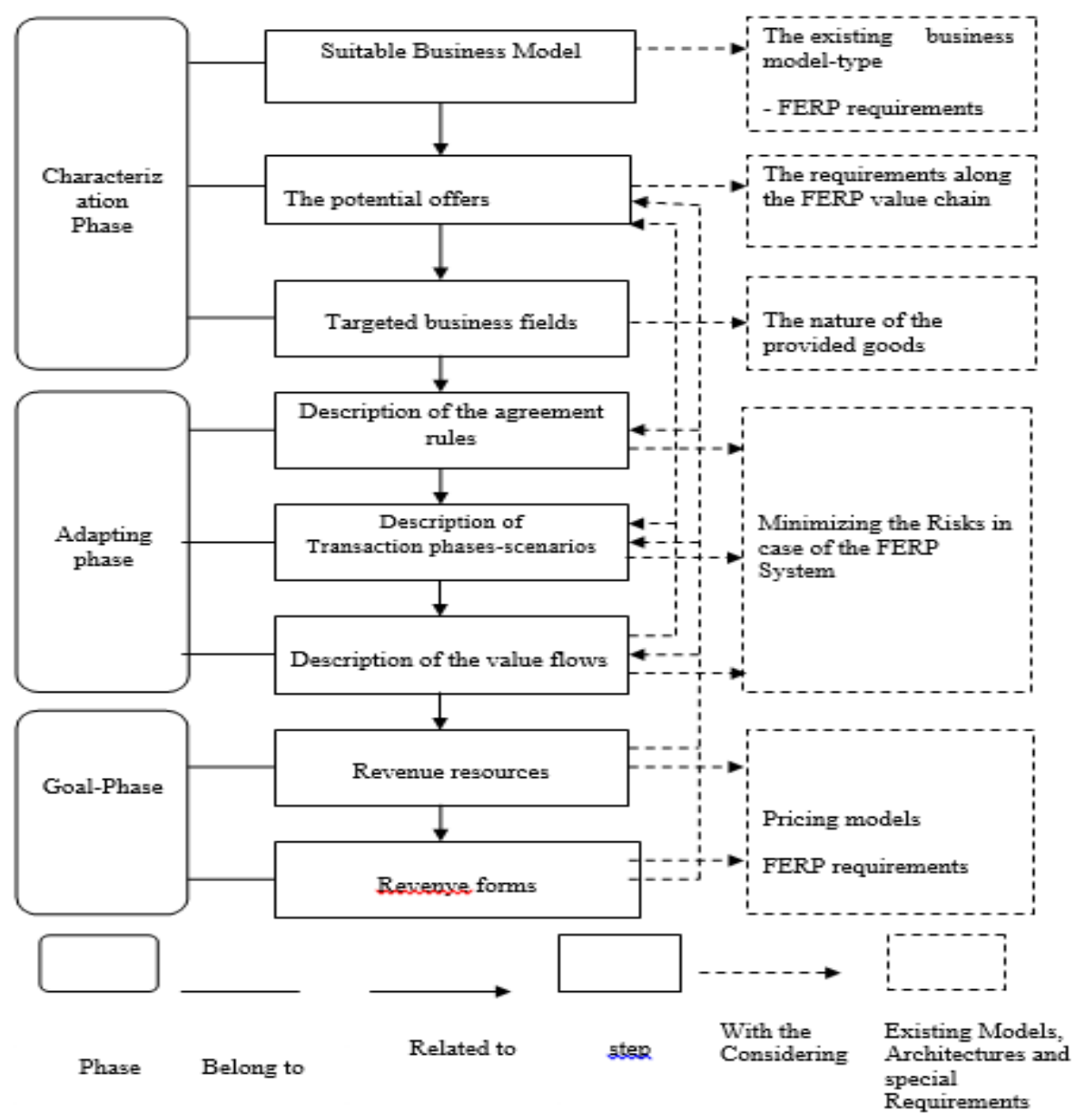

Fig. 2. Eveloping Approach for realization of Appropriate FERP Business model. 


\section{A. Characterization Phase}

In this part we will discuss the three steps that we explained previously

a) Appropriate Type of Business Model for Marketing of Distributed Erp Systems

The first step is the realization of a suitable business model for marketing of standardized and independent FERP components as WSs. It aims to develop the more suitable business model type, which can be adapted to the requirements of FERP systems Business Model discussed in [5]. The result was that the mediator's business model as a FERP mall is the closest and most appropriate type of business model to cover the lack of pre-defined communication channels and trust gap between the FERP WS providers and the end-user enterprises (SMEs). This intermediary type will be consider as the basis for the next steps by realization of FERP business model

\section{b) The Potential Offers}

As second step for characterization of a FERP mall that is identified in first step, is the identifying the expected offers in case of FERP systems. These offers to customers depend on the requirements of a FERP system along the value chain. This steps discussed also in [6]. The possible offers classified in two categories (see figure 3):
Main offers that are necessary subsystems for the realization of the FERP systems. These can be deduced from the FERP value chain. This category includes (FERP Web Services (FERP WSs, WS-publishing services and ERP Workflow-Definitions (WF-Definitions)

Supporting offers. that support the core business of the business model to be developed and strengthen related to FERP-WS providers (developers) and customers (user enterprises). Taking into account the nature of the FERP systems (as WS), This category includes Web Services Developing Environment (WSD-Environment), Testing Services (T-Services) and WS evaluation information (WSEInformation),

In the last step in this phase, we will discuss the business field of this business model according to the nature of the offers.

\section{a) The Targeted Business Fields}

Table 3 shows a classification of the goods which are exchanged through the aimed FERP Mall between the actors. , $X$ "-letter in the business field column of this table refers to X developer who develop the web services. We call it "Anonym developer" because the market in the case of FERP system is open for all the developers independent of their personalities.

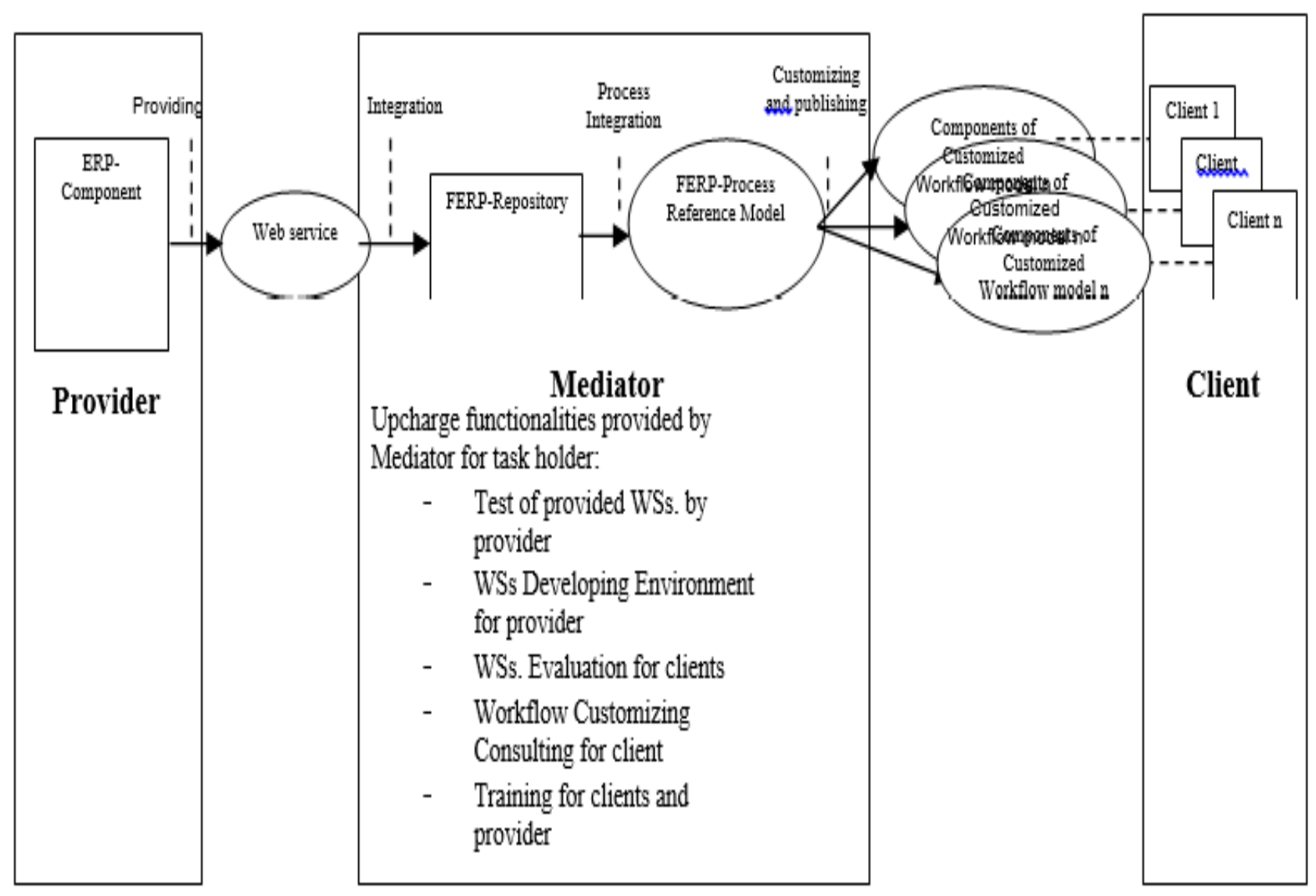

Fig. 3. FERP Scenario (or FERP value Chain). 
TABLE III. THE Business FIELDS OF THE TARGETED BUSINESS MODEL (FERP MALL)

\begin{tabular}{|l|l|l|l|}
\hline Goods & provider & costumer & Business fiel \\
\hline FERP WSs & WS Developer & User-Enterprise & X2B \\
\hline WF Definitions & Mediator & User-Enterprise & B2B \\
\hline WS Publishing & Mediator & WS Developer & B2X \\
\hline WSE Environment & Mediator & WS Developer & B2X \\
\hline T Services & Mediator & User-Enterprise & B2B \\
\hline WS Evaluations & Mediator & User-Enterprise & B2B \\
\hline Consulting & Mediator & User-Enterprise & B2B \\
\hline Training & Mediator & $\begin{array}{l}\text { The Employees of } \\
\text { the user-Enterprise }\end{array}$ & B2C \\
\hline
\end{tabular}

The goals of all the relationships through FERP Mall are business goals. Every costumer invests by making business through buying of the offered goods from the provider. Therefore, all the relationships through this mall belong to B2B field. The relation by the offering of training for the employees of the customer enterprise seems as B2C but no cash flows because the user-enterprise pay for the training curses as part of its investment. Then this FERP mall is absolute B2B business model.

As result of the characterization phase, Figure 4 represents the FERP Mall character. This mall includes several shops offering FERP WSs their functionalities belong to various business sectors.

In addition to intermediation of WSs, this mall also appears as an integrator of FERP-WSs in FERP processes through a workflow reference model that considers all possible scenarios of an enterprise. This integrator is responsible against the user enterprise for the quality of the FERP processes. This integration enables customers to cover their requirements for ERP functionality from one hand. All ERP shops among the FERP Mall look like a single ERP shop which have a single shopping and payment system

In the first phase, we have presented the first three steps from our developing approach. These steps represent the first phase (characterization-phase). Therefore, as feature work, we will discuss the role-concept of the FERP mall as mediator (intermediary) between the other parties and after that, we can present the revenue-concept of this FERP mall as the last part of the presented developing approach for the conception of FERP business model.

\section{B. Adaption Phase}

The second phase of the developing approach aims to adapting the roles and extending the intermediary's (FERP) mall for minimizing potential risks and increasing stakeholder security. This phase includes the following three steps (see Figure 2):

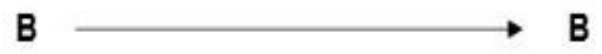

$\longrightarrow \mathrm{B}$

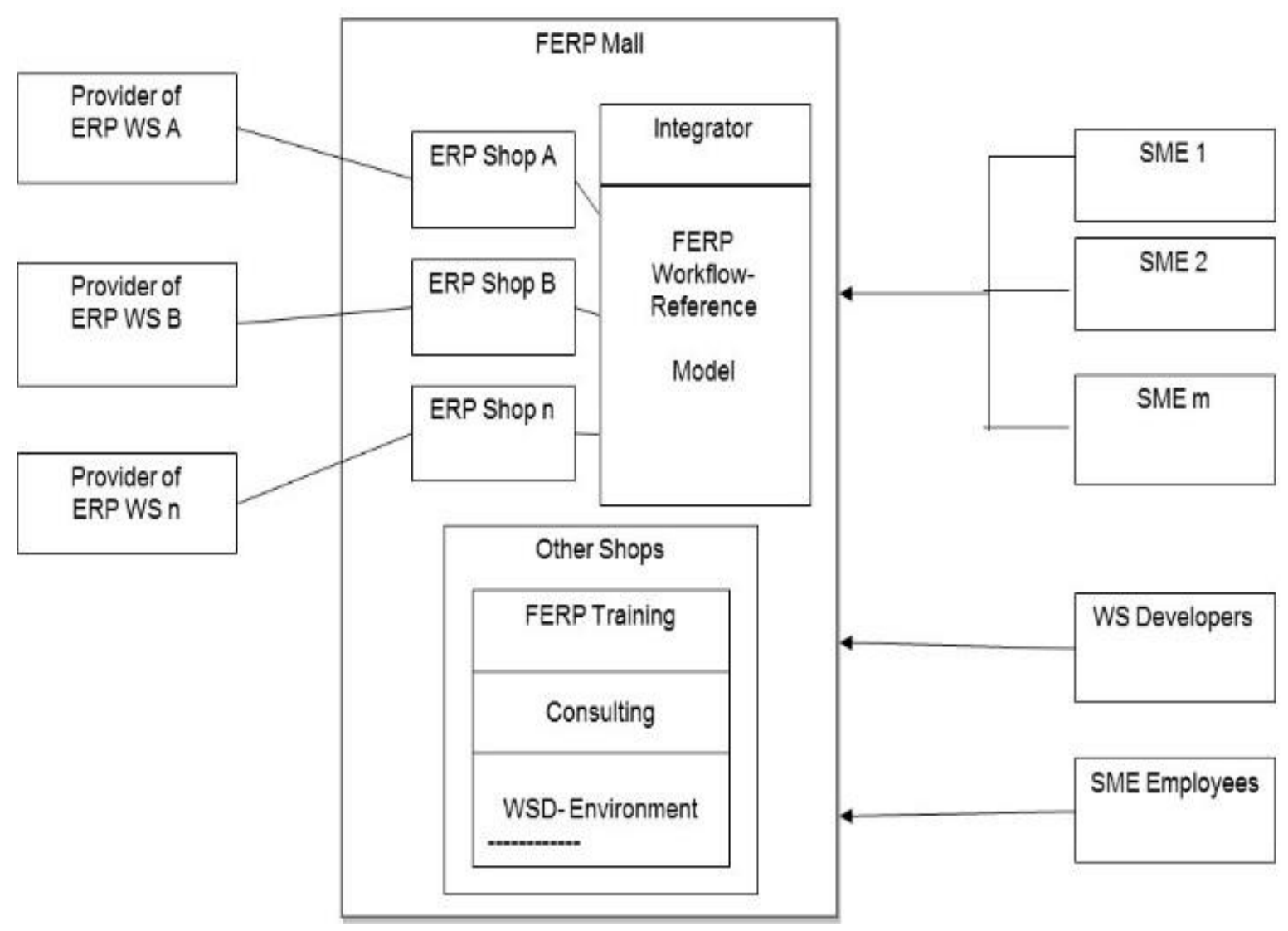

Fig. 4. The character-concept of FERP Mall 
- Description of the Service level agreement between the actors (agreement rules).

- Description of the transaction phases scenarios for user enterprises (SMEs) with different requirements.

- Description of the value flows between the actors.

In this phase should the potential to harmful risks be identified and considered by identifying the FERP Mall roles as FERP workflow designer and FERP-WS intermediary between the FERP-WS developers and the user enterprises (SMEs) during the transaction phases. The most important risk that should be considered in this phase especially in case of FERP systems is the difference between the levels of security required by SMEs. The required security level has been classified depending on survey result which has been done among hundred SMEs in Germany.

The result of this survey was: About $18 \%$ of the surveyed SMEs are allowed to make external access to their own data only from the mediator as a trusted party; approximately $45.5 \%$ of these enterprises should not allow external access to their data due to data protection and $54.5 \%$ of the surveyed SMEs confirmed that the decision in this direction is dependent on the related costs and the relevance of data protection. Because the SMEs require different security levels.. For increasing the flexibility against the various user enterprises (SMEs), the security levels required by these user enterprises can be categorized into three categories:

\section{End user enterprise from type A -with lower security level}

End user enterprise from type B -with higher security level

End user enterprise from type $\mathrm{C}$-with higher security level and/or aims to implementing external functionality as part of the internal ERP system. The user enterprises from this category use an SOA-based ERP system, which should be adapted for compatibility with the offered FERP-WSs. Lower security level means relatively low compared to the security level required by other user enterprises.

\section{a) The Agreement Rules}

To determine the FERP Mall roles, the first step in this phase is to describe the appropriate agreement rules between the FERP WS providers and the end user enterprises for all vendor or customer types, so that this mall (the mediator) will has the different Coordinate activities between the FERP WS providers (developers) and the customers (user enterprises) and it will control security against both. The agreements will be formulated in two sub-steps:

The first is service level agreement (SLA) between the providers and the mediator (FERP Mall) and the second through process level agreement (PLA) between the mediator and the end-user enterprises (for more information about this step see [6;7].

\section{b) Transaction Phases-Scenarios}

After formulating the basis for the level agreement between the actors, the second step of the adapting phase describes the possible processing scenarios of the transaction phases in the case of exchanging FERP systems with considering the different requirements of the user enterprises (SMEs).

Due to the digitizable properties of the goods offered by this business model, every transaction phase (information, negotiation and transaction phase) can be carried out online.

Processing the information and negotiation phases is the same for the three possible scenarios, but these scenarios differ in the transaction phase due to the different ways of using the required FERP-WS-Functionality

1) Information phase: FERP WS Publishing begins with the transmission of the ERP service information from the provider to the FERP Mall operator (mediator) and ended with contract signature. The FERP service information describes the static and dynamic properties of each operation of the FERP-WSs and determines the target values of dynamic properties as service-level indicators (SL-indicators). The contract defines the different conditions about the costs and the behaving way towards the customers from different types (A, B or C). The FERP Mall is the trusted party for representing the respective providers against the customer. In this phase, the mediator can check the offers by the appropriate methods.

2) Negotiating phase: The FERP mall operator (mediator) receives the demand from the customer (user enterprise) for a FERP process with the required quality (process level PL). Afterwards, the FERP Mall operator identifies the needed functionality for this process and the required quality and sends the contract including the appropriate providers list, the target values of the process levels and the costs for each provider to the costumer (user enterprise). This phase ends with the returning the contract signed by the customer. In this phase, the mediator will be informed to which type of customer (A, B or C) belongs the user enterprise.

3) Delivery and payment (transaction phase): The mediator behavior during this phase differs depending on the user enterprise type in terms of security levels (A, B and C), that will be described in the following three scenarios modeled with using the sequence diagrams:

Delivery and payment (transaction phase) for user enterprise with security level A

After the agreement between the FERP Mall operator as a representative of the FERP WS providers and the customer (user enterprises), the providers deliver the functionality by calling the FERP service operations by the customer. After the end of the FERP process, the customer returns to the mediator the information about the actual value of the PL and the mediator forwards a copy of that information to the providers, calculates the costs per (operation calls), taking into account the contractual penalty in case of non-compliance with the targeted values of the process levels and sends the resulting invoice to the customer. This phase ends with receiving the payment from the costumer. The Providers receive their shares from the mediator after deduction of the penalties (if required) due to because the providers will take the responsibility in case of non-compliance the contracted PLAs which will be 
identified by the mediator through monitoring and determining the compliance of the SLAs for each FERP-WS provider (see Figure 5).

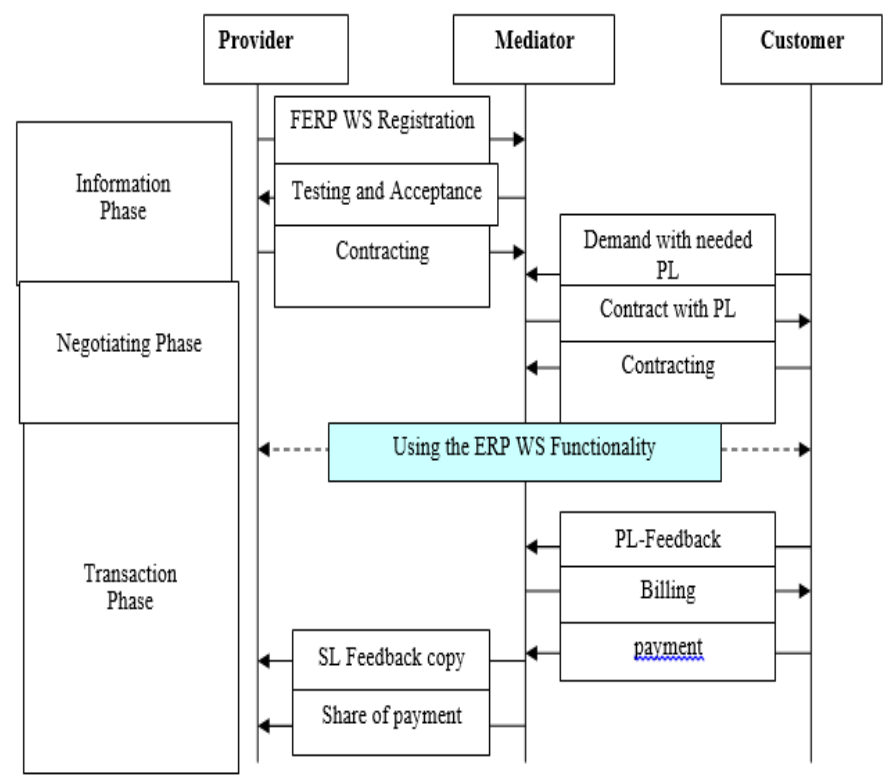

Fig. 5. FERP Mall role during transaction phases for user enterprise with security level A.

This scenario could be considered for small enterprises that don't need a high security level with considering the security solutions that has been proposed by Brehm, Marx Goemez and Rautenstrauch in $[14,22,15]$ But there are some enterprises that need more security because of their functionality sector (eg. banking sector). Such enterprises don't accept or allow to share their data with $X$ providers. Therefore, in the next subsections there are two proposed scenarios for this type of enterprises

Delivery and payment (transaction phase) for user enterprise with security level type $B$

After the agreement between the FERP Mall operator as the representative of the provider and the customer from the type $\mathrm{B}$, the FERP-WS providers will be informed about that. Then, the provider delivers the functionality structure to the mediator as a trusted party. The customer (user enterprise) uses the requested functionality by calling the FERP service operations. After the end of the FERP process, the customer returns the information about the PL's actual value to the mediator, which sends a copy of that information to the providers.

This phase ends after the payment of the invoice by the customer and each provider receives its portion of the invoice amount after deducting the resulting contractual penalties, as defined in the contract with the mediator in case of noncompliance of PLAs by monitoring and determining the compliance of the SLAs of each FERP-WS provider (see Figure 6). This scenario has the following disadvantages:

- Higher costs than scenario A because of the payment for the additional storage of the needed functionality structures by the mediator.
- If WS goes down, the replacement of another web service will take longer time than in case of scenario A

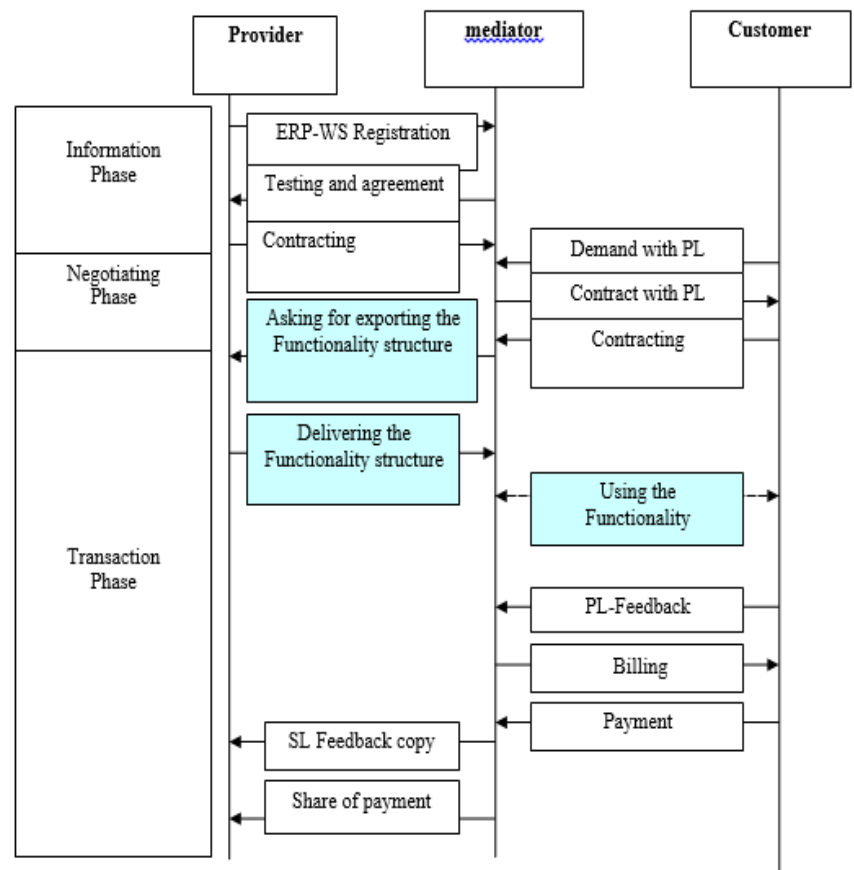

Fig. 6. FERP Mall role during transaction phases for user enterprise with security level B.

Delivery and payment (transaction phase) for user enterprise with security level type $C$

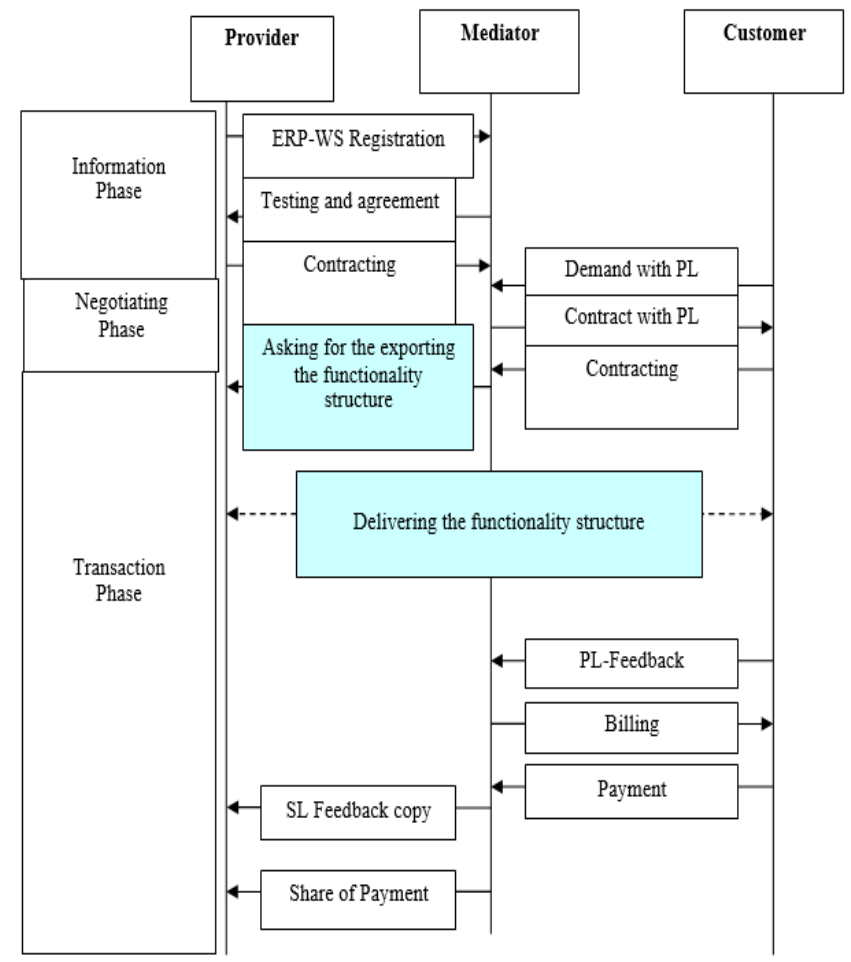

Fig. 7. FERP Mall role during transaction phases for user enterprise with security level C. 
After the agreement between the FERP Mall operator and the user enterprise from type C, the FERP-WS providers will be informed about that. Then the providers deliver the functionality structure directly to the user enterprise. In this case, the user enterprise can use the functionality internally by calling the FERP service operations. After the end of the FERP process, the customer returns the information about the actual value of the PL to the mediator and the mediator forwards a copy of that information to the providers. The, calculates the total costs, taking into account the contractual penalty for noncompliance with the targeted values of the process levels and sends the resulting invoice to the customer. In this case, the FERP-WS functionalities will be licensed for internally use. This phase ends after the customer payment and the provider will receive his portion of the invoice after deduction of the contractual penalties in case of non-compliance of agreements (see Figure 7). The costs in this case are higher than the costs in the other scenarios (A and $\mathrm{B}$ ), because the user enterprises should pay not per operation call, but by the using license and if WS goes down, the replacement of another web service will take longer time than in case of scenario A and B.

Then the end user-enterprise can choose a suitable alternative from these three scenarios depending on the comparison between the costs and the needed security from this enterprise. In the next section, we will describe the last step of adapting phase as the resulted Value flow scenarios.

\section{c) Value Flow Scenarios}

We will use use-case maps notations [28]for representing three different value flow networks due to the three types of costumers (end -user enterprise) as results of the adapting phase depending on previous interactive concepts of transaction phases .

- Value flow network of FERB business model in Scenario A:

The actors and their value creation activities are described as follows (see Figure 8):

The user enterprises represent the Market segment here, because these enterprises use the FERP systems and supporting services and pay only to the FERP-mall operator as single representative. The payment by the user enterprises will be distributed the supporting services (consulting and training) and the FERP processes (FERP Workflow Definition and FERP WS calls).

The FERP-mall operator is represented as composite actor, because he serves as (consultant, trainer, WSD environment and FERP Process Designer). The FERP-mall operator distributes the payments to the customers participating in the ERP process as providers of FERP-WS functionalities. The provider shares are billed depending on the FERP-WS-calls after the deduction of intermediation fees.

The ERP WS providers are represented as a market segment, because they develop the FERP-WS functionalities for different business sectors using the WSD environment offered by the FERP-mall operator and publish these WSs by this operator against certain fees. There is no direct money flows between the end user enterprises and the FERP-WS- providers because the payment for the WS calls go only through the intermediary (FERP-mall operator).

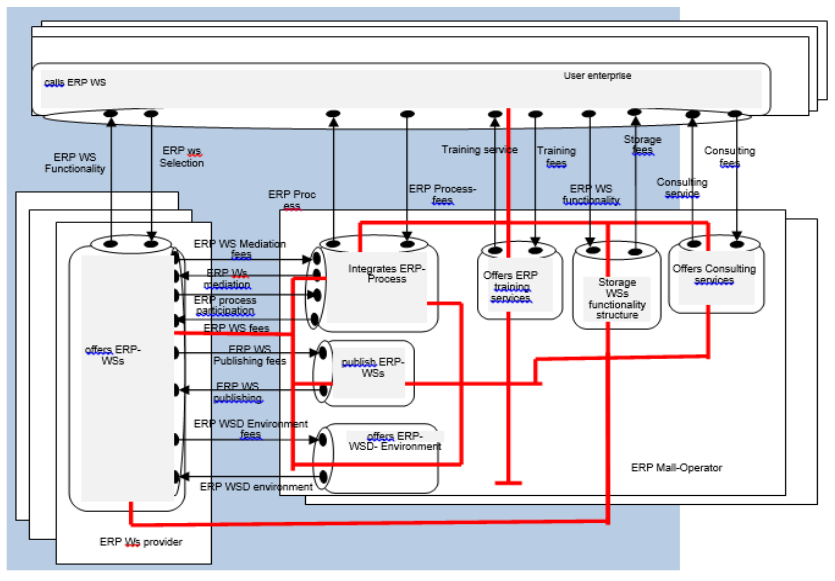

Fig. 8. Value Flows of FERP business model for customer type A.

- Value flow network of FERB business model in Scenario B:

The value flows of this scenario are derived from Scenario A by expanding the FERP-mall operator role for storing the functionality structures of FERP WSs, which are selected by the user enterprises (see Figure 9)..

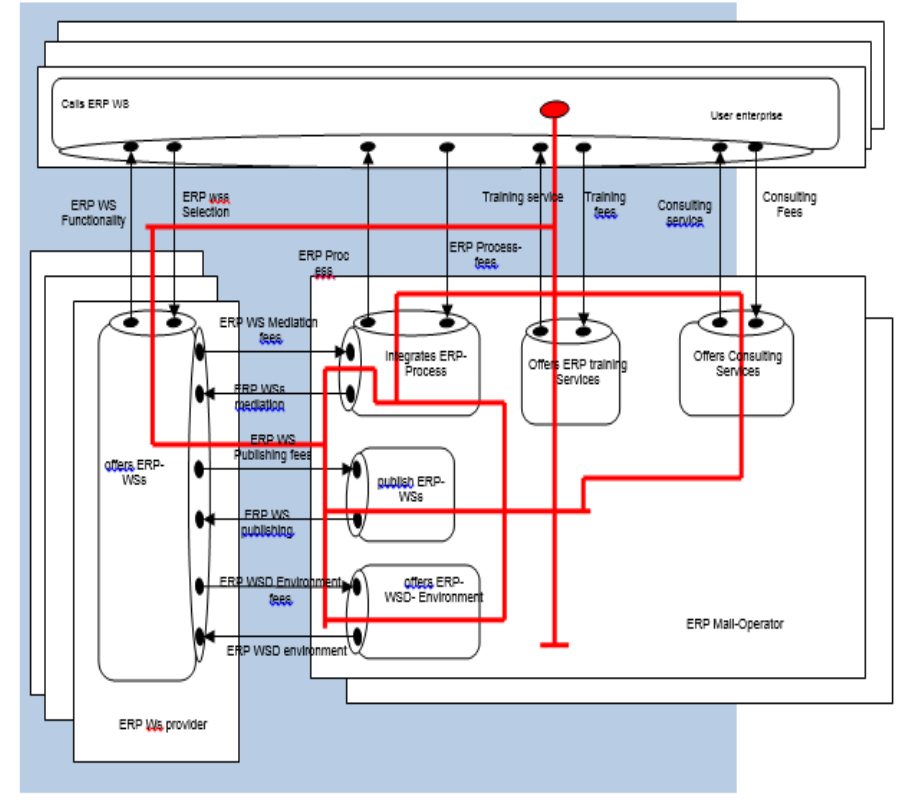

Fig. 9. Value Flows of FERP business model for customer type B.

The storage fee is paid from the use of WS-FERP functionality for increasing the safety for the users (customers).

In this scenario, there is no direct connection between the FERP-WS providers and the user (customers), since the FERPWS functionalities are used by the mediator (FERP mall).

With the delivery of he WS functionality structures to the mediator (FERP mall), the FERP-WS providers expand their 
market shares through the users who require a relatively higher level of security .

- Value flow network of FERB business model in Scenario C:

The difference between this scenario and Scenario A is only by the delivery of the selected functionality structures of FERP WSS instead of WS-functionality between FERP-WS providers and user enterprises. The business model in the two scenarios (A and $\mathrm{C}$ ) has a similar value flow network (see Figure 10). In the case of scenario $C$ there is no direct cash flows between the operating enterprises (costumers) and the FERP-WS-party because the payment well be payed for FERP-WS functionality licensing by the user enterprises only through the FERP mall

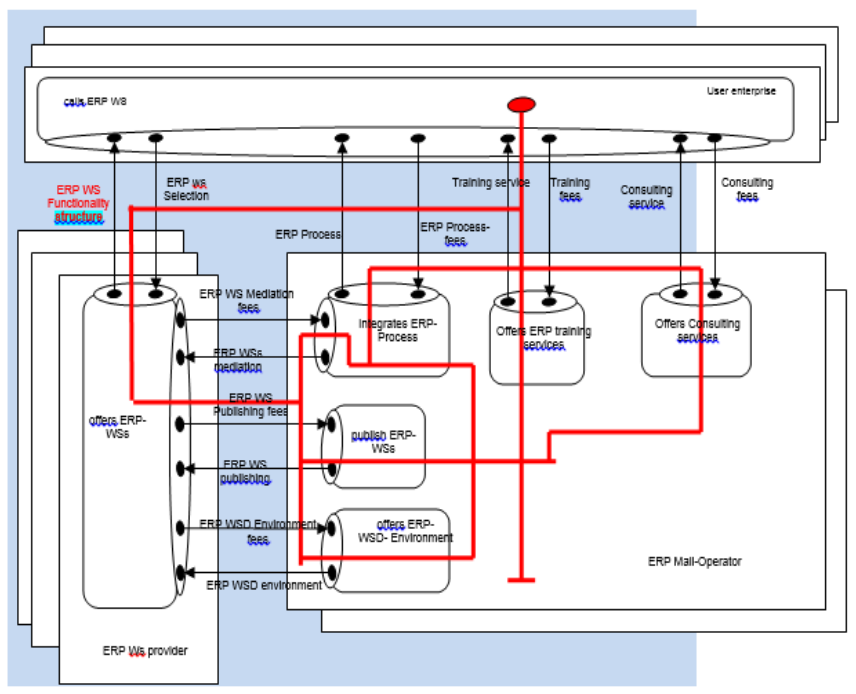

Fig. 10. Value Flows of FERP business model for customer type C.

\section{Goal Phase}

The last phase of the developing approach is determining the revenue model of the business model as result concept depending on the characterization and adapting steps. The goal of any business model is the generation of revenues for increasing the efficiency of the model. The figure 11 shows the concept of possible revenue model due to the determination of the offers and the roles of FERP mall. As the figure 11 shows the revenue will be generated through:

- selling FERP-WSs, the WSD environment (as services), consulting and training services $=$ (Direct and transaction-dependent revenue)

- $\quad$ selling WSs because of FERP-WS-market is open to everyone FERP-WS developer $=$ (Direct and transaction-dependent revenue)

- FERP-WS-publication (WS- advertising) = (indirect and transaction-independent revenue)

- Intermediation of the data storage and transaction phases between FERP-WS providers (developers) and the different types of customers (corporate users) = (Indirect and transaction-dependent revenue)

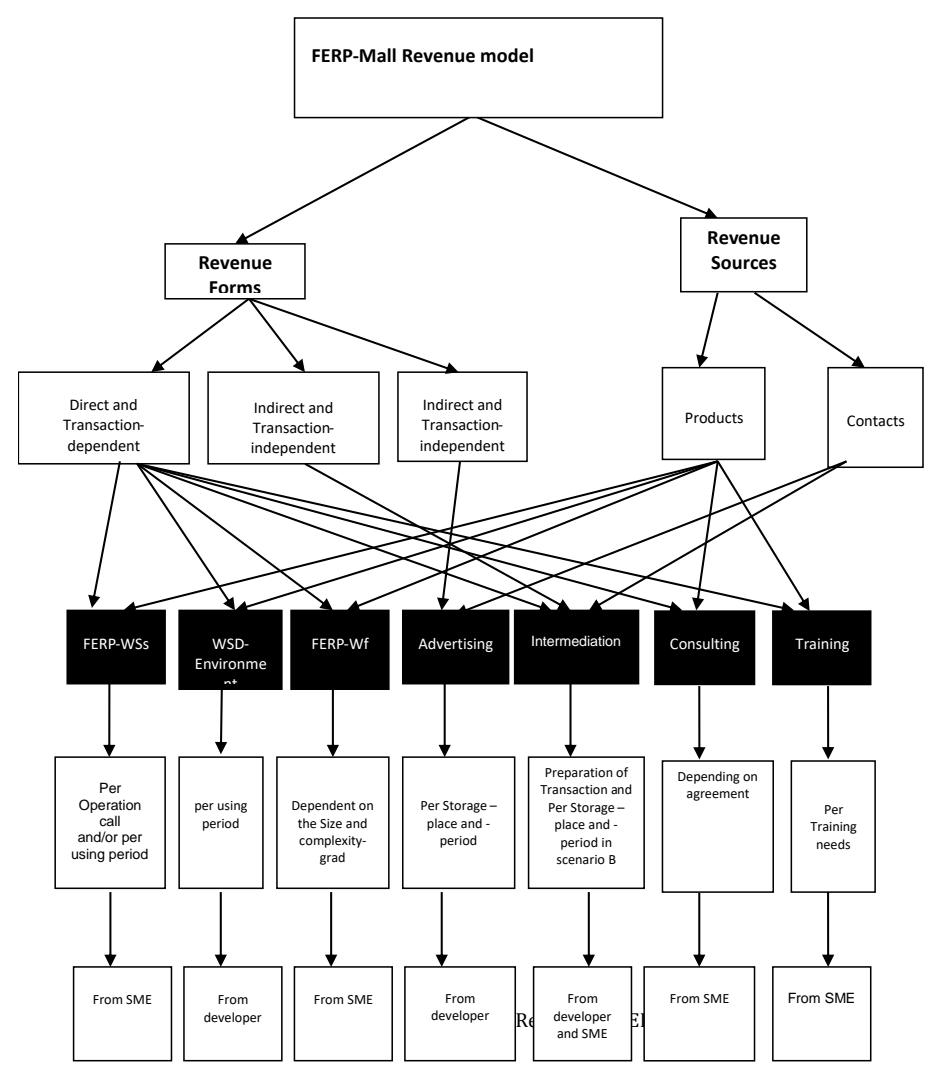

Fig. 11. Revenue of FERP Mall.

\section{Qualitative Evaluation}

This evaluation focuses on the classification of the various added values that arise from the perspective of the participating actors in the FERP business model. This informational added values are divided into ten categories [36; 48] (please see table 4:

\section{Qualitative Evaluation By INTERVIEWING A TARGET GROUP}

For the evaluation of the acceptance of the FERP System and FERP Mall idea as a solution for covering the company's requirements for the ERP functionality, we did survey among a target group of these companies, which are working as service providers and / or as manufacturers, and Sellers of physical and digitizable products. For this survey, approximately 120 invitations were sent to the SMEs in Saxony-Anhalt in Germany by fax and e-mail. The invitation included a brief summary of the FERP System and FERP Mall ideas. 33 of the invited companies accepted to participate in the survey. The contacts with the surveyed companies were carried out as follows:

- $73 \%$ personally

- $27 \%$ by e-mail 
TABLE IV. INFORMATIONAL AdDED VALUE

\begin{tabular}{|c|c|c|}
\hline $\begin{array}{l}\text { End user enterprise } \\
\text { (customer) }\end{array}$ & Mediator & FERP-WSs provider \\
\hline \multicolumn{3}{|l|}{ Comparative Added value } \\
\hline $\begin{array}{l}\text { 1- The user enterprise may test the generated FERP } \\
\text { process by FERP mall before the life time } u\end{array}$ & 1- The FERP mall can test the publishing. & \\
\hline \multicolumn{3}{|l|}{ Integrative Added value } \\
\hline & $\begin{array}{l}\text { 1- The FERP Mall offers reusable FERP processes } \\
\text { which integrate FERB WSs of various developer }\end{array}$ & \\
\hline \multicolumn{3}{|l|}{ Organizational Added value } \\
\hline & $\begin{array}{l}\text { 1- In the case of ERP systems the FERP mall appears } \\
\text { as a virtual enterprise for offering the FERP workflow } \\
\text { definitions, the online directory services and support } \\
\text { services }\end{array}$ & $\begin{array}{l}\text { 1- In the case of the ERP systems. The } \\
\text { FERP-WS- developer appears as a } \\
\text { enterprise, which offer FERP-WSs } \\
\text { according to an respective competence. }\end{array}$ \\
\hline \multicolumn{3}{|l|}{ Strategic added value } \\
\hline & $\begin{array}{l}\text { 1- The FERP mall can provide worldwide market } \\
\text { transparency by publishing FERP WSs with their } \\
\text { marketing-information, the reviews and the safety } \\
\text { rules. }\end{array}$ & $\begin{array}{l}\text { 1- The FERP-WS provider can provide } \\
\text { more Market transparency by publishing } \\
\text { his FERP-WSs and its evaluations. }\end{array}$ \\
\hline \multicolumn{3}{|l|}{ Innovative Added value } \\
\hline $\begin{array}{l}\text { 1- The interactive relationship between the intermediary } \\
\text { and the developers helps for offering an adapted FERP } \\
\text { WSs, FERP workflows and support services to the } \\
\text { individual needs of the user enterprises. }\end{array}$ & $\begin{array}{l}\text { 1- Offering ERP functionalities as WSs will open the } \\
\text { door for providing new products and services for } \\
\text { Supporting FERP customers and FERP-WS developers } \\
\text { (e.g. FERP workflow definitions and other services) }\end{array}$ & $\begin{array}{l}\text { 1- The provider offers new form of the ERP } \\
\text { functionality as WS of which can be } \\
\text { combined with other WSs providers with } \\
\text { other WSs. }\end{array}$ \\
\hline \multicolumn{3}{|l|}{ Added values with efficiency effects } \\
\hline $\begin{array}{l}\text { 1- Reducing the costs, because the user enterprises pay } \\
\text { only for the used functions (pay as you go). } \\
\text { 2- reducingReducing the costs through competition } \\
\text { between FERP-WS providers of similar FERP-WSs. } \\
\text { 3- reducing the cost, because in the case of FERP system } \\
\text { less end hardware are needed. } \\
\text { 4- The user enterprises can achieve cost advantages } \\
\text { through purchasing FERP-WSs with other support services } \\
\text { in one package directly from the mediator. } \\
\text { 5- The user enterprises can reduce time and cost through } \\
\text { faster replacement in case of failure of a Web service. } \\
\text { 6- The user enterprises can have the needed FERP System } \\
\text { faster because of the online availability of ERP } \\
\text { components and the faster } \\
\text { adaptability of FERP processes }\end{array}$ & $\begin{array}{l}\text { 1- The mediator can adapt in less time the needed } \\
\text { FERP workflow by the user-enterprise ERP processes. } \\
\text { 2- The mediator generates revenue through the } \\
\text { mediation of FERP-WSs, offering FERP workflow } \\
\text { definitions and the supporting services. }\end{array}$ & $\begin{array}{l}\text { 1- The FERP-WS provider (developer) can } \\
\text { reduce development time by using the } \\
\text { WSD environment, which is offered by the } \\
\text { mediator. } \\
\text { 2-The REUSE-applicability of FERP-WSs } \\
\text { increases the efficiency because the } \\
\text { variable costs are near to zero }\end{array}$ \\
\hline \multicolumn{3}{|l|}{ Added values with efficiency effect } \\
\hline $\begin{array}{l}1 \text { Selection of the needed ERP functionalities is facilitated } \\
\text { by the offered information about the FERP-WSs from the } \\
\text { different providers. }\end{array}$ & $\begin{array}{l}\text { 1- The FERP mall can increase customer satisfaction } \\
\text { because of the safety levels as well as through the } \\
\text { supporting services, thereby improving their market } \\
\text { shares. }\end{array}$ & \\
\hline \multicolumn{3}{|l|}{ Flexible Added value } \\
\hline & $\begin{array}{l}\text { 1-FERP processes can be cheaper and faster adapted } \\
\text { by the user enterprise }\end{array}$ & $\begin{array}{l}\text { 1-The online availability of the ERP } \\
\text { component shortens the delivery time. }\end{array}$ \\
\hline \multicolumn{3}{|l|}{ Aesthetic Emotional added value } \\
\hline \multicolumn{3}{|l|}{ Macroeconomic added value } \\
\hline $\begin{array}{l}\text { 1- changing the required qualifications of the employees } \\
\text { by the user enterprises. } \\
2 \text { - changing the IT infrastructure of the user enterprises. }\end{array}$ & & $\begin{array}{l}\text { 1- A possible change the developing and } \\
\text { offering form of information systems in the } \\
\text { market. }\end{array}$ \\
\hline
\end{tabular}


During the execution of this survey, various problems and difficulties were faced. The most relevant difficulties were:

- Difficulties by gathering the addresses of the surveyed target group due to data protection laws,

- Difficulty in understanding the ideas of the FERP systems and the FERP Mall by the employees of the surveyed companies. Therefore, this questionnaire has been explained by a short presentation.

- The results of the survey are shown below:

1) The surveyed companies has been chosen from different size (number of employees). The ratios of company size are listed in Table 5 in three categories

TABLE V. PRoportion of COMPANIES SURVEYEd DEPENDING ON THE NUMBER OF EMPLOYEES

\begin{tabular}{|l|r|r|r|}
\hline \multicolumn{1}{|c|}{ number of employees } & $\mathbf{1 - 6 0}$ & $\mathbf{6 1 - 1 5 0}$ & $>\mathbf{1 5 0}$ \\
\hline Proportions & $6.63 \%$ & $27, .3 \%$ & $9, .1 \%$ \\
\hline
\end{tabular}

2) All surveyed companies use more than one information system. $85 \%$ of them use 2 to 5 systems that provide functions to cover the different sectors (see table 6).

TABLE VI. FUNCTIONALITY OF THE INFORMATION SYSTEMS USED IN THE SMES

\begin{tabular}{|l|l|}
\hline Functionally Sectors & proportions \\
\hline Finance and accounting & $63.6 \%$ \\
\hline Customer management & $63.6 \%$ \\
\hline Distribution & $63.6 \%$ \\
\hline Payroll & $54.5 \%$ \\
\hline Cost accounting & $45.4 \%$ \\
\hline Procurement & $27.3 \%$ \\
\hline warehousing & $36.4 \%$ \\
\hline Human resource management & $54.5 \%$ \\
\hline Production Planning and Control & $36.4 \%$ \\
\hline project management & $81.8 \%$ \\
\hline quality management & $63.6 \%$ \\
\hline Research and Development & $9.1 \%$ \\
\hline
\end{tabular}

$-82 \%$ of the surveyed companies have confirmed that the idea of a FERP mall is a good idea. However, $22 \%$ of these had additional comments, like

- Whether this idea is also suitable for very small companies,

- And whether the user company can test the new replacement solution.

3) Table 7 explains the answers to the question of the responsibility for defining the appropriate workflows among the user companies. From this table it can be deduced that a favorable definition of the workflow of the user companies can take a market share (about $9.1 \%+36.4 \%=45.5 \%$ ) for offering such products (see table 7).
TABLE VII. POSSIBILITIES OF ADOPTING WORKFLOW DEFINITIONS AMONG THE SURVEYED SMES

\begin{tabular}{|l|l|}
\hline $\begin{array}{l}\text { A definition of the workflow can be created by employees } \\
\text { within the company and they take the responsibility for it. }\end{array}$ & $63.6 \%$ \\
\hline A definition of workflow can be made by the FERP Mall itself. & $9.1 \%$ \\
\hline That depends on the cost. & $36.4 \%$ \\
\hline
\end{tabular}

4) About $55 \%$ of the companies have confirmed that training their employees is necessary to introduce a FERP system. $25 \%$ of these companies consider the request for such training possible or useful. The estimated market share of these services is about $55 \%+27 \%=82 \%$.

5) About $73 \%$ of the companies have confirmed that consulting is needed in the case of FERP system. $18 \%$ of these companies consider the request for such consulting possible and useful. The estimated market share of these services is about $73 \%+18 \%=91 \%$.

6) Table 8 describes the possible storage location of the company data in case of FERP system from the point of view of the surveyed user companies (SMEs): From this table it can be deduced that the possibility of storing the data by the FERP Mall as a trusted party which Controls costs and data security can be increased.

TABLE VIII. LOCATION OF COMPANY DATA From SMES POINT OF VIEW

\begin{tabular}{|l|l|}
\hline Storing Place & Proportions \\
\hline By FERP Mall as a trusted party & $18.2 \%$ \\
\hline by the user company itself & $45.4 \%$ \\
\hline $\begin{array}{l}\text { This depends on the associated costs and the relevance } \\
\text { of data protection. }\end{array}$ & $54.5 \%$ \\
\hline
\end{tabular}

7) Possible problems in case of FERP system from the interviewed companies point of view are:

- Problems due to the required data security.

- The existing platform in some companies is small and not very suitable for using such system.

- The extra effort duiring the shifting to such system and the necessary training.

- Some of the user companies are in close contact with the suppliers. Therefore, this supplier should also be able to adapt to such systems.

- SMEs are often very specialized - so the software has to be flexible enough to be adapted for " peculiarities " of the SME. z. For example, there are sometimes very significant differences in the interfaces of SMEs belonging to a similar area.

Most of these issues have been taken into account by the processing of the technical and / or economical part of the FERP idea. Regarding to some cases of close connection between the user companies and the suppliers, the suppliers can adapt to the new systems in order to satisfy their customers (user companies). 


\section{DISCUSSION}

The most of existing articles in Business model field aimed mostly to increase knowledge about the theoretical definition and classification aspects and of an business model and its components (see $[41 ; 50,34.33,53]$ ) identified strategic framework for managing business model innovation (BMI) but they didn't identify clearly logical steps that explain: how we can realize suitable business model for innovative business Ideas. It is very important to refer in this context that the previous researches focused on the business models from management side in general without consideration of specific business area especially that are related to the information technology (like as a service paradigm) which need specific background and analysis. Some of the researches that focused on cloud computing as a service paradigm (like [29]) provided business concept for providing Modeling \& Simulation (M\&S) as a service without to formulize the analytical steps that lead to these concept.

The gap between the aim of this research and the other related research works is that this research focused on deriving and formulizing a suitable developing approach, which provides logical steps that lead significantly to realize the appropriate business model concepts in general and for distributed business information system. The provided approach in this research was as result of business and technical analysis to give framework for developing various type of business ideas with business and it perspectives because it considers a relevant version of ERP System to be provided as a service.

\section{CONCLUSION}

This work presents three-phase- developing approach for designing appropriate business model for exchanging federated ERP systems on basis of WSs. The results of this developing approach are three sub-models (as concepts). These submodels are, the character, the role model and the revenue model, which together formulate a FERP mall business model. The main type of this business model is a hybrid form as commercial intermediary for covering the lack of pre-defined communication channels and areas of responsibility between the respective developers and the user-enterprise as well as an online shop by offering support services and Workflow definitions. This business model belongs either to content business model type by offering online training services. This Idea also has been quantities and qualitative evaluated.

\section{REFERENCES}

I [1] S. Abels, N. Brehm, A. Hahn and J. M. Gómez: Change management issues in federated ERP-systems" An approach for identifying requirements and possible solutions. International Journal of Information Systems and Change Management (IJISCM), 1, pp. 318-335. (2006).

[2] D. Abts, and W. Mülder: Grundkurs Wirtschaftsinformatik", Eine kompakte und praxisorientierte Einführung, 4. Aufl., Braunschweig et al. (2002).

[3] A. Afuah, Business Models: A Strategic Management Approach. New York: McGraw-Hill/(2003).

[4] B. Al-Sawaie and Z. Al-Salti,: `Enterprise Resource Planning (ERP) Adoption: An Exploratory Case Study from Oman', 26th IBIMA International Conference proceedings, Spain (2015).

[5] E. Asfoura, N. Jamous and W, Salem: The economic classification of ELearning business models, In: Institute of Electrical and Electronics
Engineers: IEEE multidisciplinary engineering education magazine. New York, NY: IEEE, Bd. 4, 1, S. 8-12 (2009).

[6] E. Asfoura, G. Kassem and R. Dumke:.Characterization of business model for federated ERP systems, in: International Journal of u- and eService, Science and Technology Vol. 3, No. 4, December, 2010, S. 193

[7] E. Asfoura, G. Kassam and R. Dumke: Kombination von Service, Process Level Agreement und Zahlungsverhalten für sichere FERP Malls , In: Workshop Bewertungs aspekte serviceorientierter Acrhitekturen. BSOA 2009; Darmstadt-Germany.

[8] E. Asfoura, N. Jamous, G. Kassem and R. Dumke, R: FERP mall role in FERP web services marketing In: International Conference on Information Society (i-Society) . - Informations Society,IEEE, ISBN 978-0-9564263-3-8, (London, UK)2010, S. 156-161

[9] E. Asfoura, N. Jamous, G. Kassam and R. Dumke: E-mall as solution for marketing the federated ERP components on the basis of web services, In: International review of business research papers . - Melbourne, Bd. 5. 4, S. 478-490 (2009).

[10] E. Asfoura, G. Kassem, N. Jamous and R. Dumke: Pricing-model for marketing of FERP-Workflow as product. In: fifth International Conference on Digital Information Management . - Piscataway, NJ : IEEE, ISBN 978-1-424-47571-1, S. 321-325Kongress: ICDIM; (Thunder Bay, Canada) 2010 .07.05-08.

[11] E. Asfoura, G. Kassem, and R. Dumke:.Characterization of business model for federated ERP systems, in: International Journal of u- and eService, Science and Technology Vol. 3, No. 4, December, 2010, S. 193

[12] E. Asfoura, G. Kassam and R. Dumke: Kombination von Service, Process Level Agreement und Zahlungsverhalten für sichere FERP Malls , In: Workshop Bewertungs aspekte serviceorientierter Acrhitekturen. BSOA 2009; Darmstadt-Germany.

[13] F. A. Boons and F. Ludeke-Freund,; Business " models for sustainable innovation: State-of-the-art and steps towards a research agenda. Journal of Cleaner Production, 45: 9-19 (2013).

[14] N. Brehm, J. M., Gómez and C. Rautenstrauch: “ An Open Security Model for Web Service-based ERP Systems. , in: 4th Annual Security Conference, Las Vegas, USA, 2005.

[15] N. Brehm and J. M., Gómez : Securing Federated ERP system clients. GITMA World Conference - Global Information Technology Management Association, Orlando, Florida, USA, 2006.

[16] N. Brehm and J. M., Marx Gómez, J : Distribution of ERP system components and security considerations. 17th IRMA Intenational Conference - Managing Modern Organizations with Information Technology. Washington D.C., USA, 2006a.

[17] E. Asfoura, Abdel-Haq MS, and Chatti et al. (2018). Classification of business models with focusing on characterizing "as a service" offers. International Journal of Advanced and Applied Sciences, 5(11): 16-23

[18] N. Brehm and J. M. Gómez : The Web Service-based combination of data and logic integration on Federated ERP systems, 18th IRMA International Conference - Managing Modern Organizations with Information Technology, Vancouver, Canada (2007).

[19] N. Brehm and J. M. Gomez, :Federated ERP-Systems on the basis of Web Services and P2P networks, International Journal of Information Technology and Management (IJITM), pp- 75-89 (2010).

[20] N. Brehm and J. M Gómez: Web Service-basierte Referenzarchitektur für Föderierte ERP-Systeme. In: (Pietsch, T.; Lang, C.V. Hrsg.): Ressourcenmanagement. Erich Schmidt Verlag, Berlin, pp. 125142.1875 (2007a).

[21] N. Brehm, J. M . Gómez. And H. Strack: Request-Response-Evaluation Infrastructure for trusted Web Service-based ERP systems, In: C. Rautenstrauch (Hrsg.), Die Zukunft der Anwendungssoftware - die Anwendungssoftware der Zukunft. Aachen: Shaker Verlag. pp. 83 - 93 (2007).

[22] N. Brehm and J. M. Gómez.: Sicherheitsprotokoll zur Bewertung von Diensten in SOA-basierten Anwendungssytemen, in: BSOA Workshop Bewertungsaspekte Serviceorientierter Architekturen, Berlin (2006).

[23] N. Brehm, J. M. Gómez and A. Ziesenitz: Toolunterstützung bei der vermarktungs orientierten Entwicklung von Web Services als Bausteine 
komplexer betrieblicher Anwendungssysteme, in: proceeding of Multikonferenz Wirtschaftsinformatik, München/Garching (2008).

[24] D.J Collins and K.P. Lam Selling the Cloud to Smaller Business Organisations", Journal of Cloud Computing, Vol. 2014 (2014), Article ID 586109, DOI: 10.5171/2014.586109

[25] C. R.; Cunha, E, P. Morais; J, P, Sousa and J, P, Gome: The Role of Cloud Computing in the Development of Information Systems for SMEs, in Journal of Cloud Computing http://www.ibimapublishing.com/journals/JCC/jcc.html Vol. 2017 (2017),

[26] D. Debelak: Business model made easy. Wisconsin: CWL Publishing Enterprises (2006)

[27] J, M. Gronau.: Enterprise Resource Planning und Supply Chain Management, Archite-ktur und Funktionen. München (2004).

[28] J. Gordijn, J. M. Akkermans and J. C. van Vliet: What's in an Electronic Business Model. In: Proc Knowledge Engineering and Knowledge Manag-ement,12th Int'l Conf. (EKAW 2000), Springer Verlag,Berlin, 2000, vol. LNAI 1937, pp. 257-273.

[29] Kiss et al : BUSINESS MODELS FOR CLOUD COMPUTING: EXPERIENCES FROM DEVELOPING MODELING \& SIMULATION AS A SERVICE APPLICATIONS IN INDUSTRY, in: Proceedings of the 2015 Winter Simulation Conference

[30] V. Kumur and G. Raheja : BUSINESS TO BUSINESS (B2B) AND BUSINESS TO CONSUMER (B2C) MANAGEMENT, in : International Journal of Computers \& Technology, Volume 3 No. 3, Nov-Dec, (2012)

[31] R. Maleri: Grundlagen der Dienstleistungsproduktion, 3. vollst. ueberarb. Aufl., pp 50, Berlin (1994)

[32] J. Magretta: Why Business Models Matter. Harvard Business Review on Business Model Innovation. USA: HBR Publishing Corporation (2010).

[33] Malmström et al: Practicing business model management in new ventures, Journal of Business Models, Vol. 5, No. 1, pp. 1-13(2017)

[34] L. Massa, C. L. Tucci and A. Afuah: A Critical Assessment of Business Model Research, in: Academy of Management Annals Vol. 11, No. 1(2017)

[35] M. Merz: E-Commerce und E-Business Marktmodelle, Anwendungen und Technologien ,Kap. 3 dpunkt Verlag, Heidelberg (2001).

[36] C. Rautenstrauch and T. Schulze: Informatik für Wirtschaftswissenschaftler und Wirtschaftsinformatiker, Berlin (2003).

[37] W. Reim, V. Parida and D. Ortqvist. .. Product " -Service Systems (PSS) business models and tactics: A systematic literature review. Journal of Cleaner Production, 97: 61-75 (2015.

[38] D., J. Robey, J Ross and M. Boudreau: Learning to implement enterprise system, An exploratory study of the dialectics of change. Journal of Management Information Systems, pp. 1746 (2002).
[39] C. Scheer and P. Loos: Internetbasierte Geschäftsmodelle ; Neue Möglichkeiten der Wertschöpfungsorganisation in der InternetÖkonomie“ (2001).

[40] S. Slávik: Komparatívna analýza podnikatel’ských modelov. Ekonomika a manažment, 11(3), 23-43 (2011).

[41] S. Slávik and R. Bednár: Analysis of Business Models. Journal of Competitiveness, 6 (4), 19-40 https://doi.org/10.7441/joc.2014.04.02 (2014).

[42] B. Skiera and A. Lambercht: Erlösmodelle im Internet, in Herrmann, A., Albers, (Hrsg.), pp. 817 (2000).

[43] D. Stelzer.: Digitale Güter und ihre Bedeutung in der Internet-Ökonomi (2000).

[44] S. Y. Stephen and H. G. An: Software Engineering Meets Services and Cloud Computing, in: Published by the IEEE Computer Society OCTOBER (2011)

[45] T. F.; Stillman, F. D. Fincham,; D.V. Kathleen; V. M. N. Lambert and C. Phillips: The material and immaterial in conflict: Spirituality reduces conspicuous consumption, in: Journal of Economic Psychology 33 (2012) 1-7

[46] P. Timmers: Business Models for Electronic Markets". in: Electronic Markets 8(2) (1998)

[47] K. Turowski, K.: Fachkomponenten: Komponentenbasierte betriebliche Anwendungssysteme," Aachen (2003).

[48] Turowski and K. Pousttchi: Mobile Commerce. In: Springer Verlag Berlin.

[49] Usability First, (2016). [online]. [Viewed 17.04.18]. Available from: http://www.usabilityfirst.com/about-usability/web-applicationdesign/erp-systems/

[50] B. Verhoeven and L. W. Johnson,: Business Model Innovation Portfolio Strategy for Growth Under Product Market Configurations, Journal of Business Models, Vol. 5, No. 1, pp. 35-50 (2017)

[51] P. Wells: Economies of scale versus small is beautiful: A business model approach based on architecture, principles and components in the beer industry. Organization \& Environment, 29: 36-52 (2016)

[52] . B. W.Wirtz.: electronic Business",-243, Wiesbaden (2001).

[53] W3C., 2003. Web service architecture, working Group note, im WWW unter http://www.w3.org/TR/ws-arch /wsa.pdf (15.03.(2008).

[54] R. Amit and Zott, Ch. (2001): Value Chain in E-Business. In: Strategic Management Journal, 22, S. 521.

[55] B. Heinrich and Leist, S. (2000): Bankenarchitekturen im Informationszeitalter - Zur Rolle des Geschäftsmodells. In: Österle, H.; Winter, R. (Hrsg.): Business Engineering - Auf dem Weg zum Unternehmen des Informat-ionszeitalters. Springer-Verlag, Berlin Heidelberg New York, S. 141-165.

[56] Mercer Management Consulting (2002): Herausforderung profitables Wach-stum. Pressemitteilung vom 02.12.2002, http://www.mercermc.de/uploadmaterial/61.zip 